\title{
N-remineralization of phyto- and bacterioplankton by the marine ciliate Euplotes vannus
}

\author{
V. Gast and U. Horstmann \\ Institut für Meereskunde an der Universität Kiel, D-2300 Kiel, Düsternbrooker Weg 20, Federal Republic of Germany
}

\begin{abstract}
Ammonia excretion by the marine ciliate Euplotes vannus was investigated with the aid of feeding experiments involving algal food organisms (Dunaliella tertiolecta) and a bacterial diet (Vibrio sp.). The ciliates displayed a typical growth curve with a generation time of 6.2 to $6.9 \mathrm{~h} \mathrm{at} 25^{\circ} \mathrm{C}$. With increasing consumption of the preferred food organisms by ciliates a steady increase in ammonia content of the culture medium was observed. During the logarithmic growth phase Euplotes vannus excreted $0.22 \times 10^{-5}$ and $0.41 \times 10^{-5} \mu \mathrm{mol} \mathrm{N}$ ciliate ${ }^{-1} \mathrm{~h}^{-1}$, utilizing algal and bacterial nourishment, respectively. The role of ciliates in the regeneration of inorganic nutrients in water is discussed.
\end{abstract}

\section{INTRODUCTION}

Continuous primary production in the euphotic zone of aquatic systems without nutrient input depends on regeneration of inorganic phosphorus and nitrogen compounds. Together with bacteria, zooplankton are important in the remineralization on plant-derived nutrients. There are numerous studies of excretion of inorganic nutrients by larger zooplankton (Harries, 1959; Conover and Corner, 1968; Butler et al., 1969; Conover and Mayzaud, 1976; Quetin et al., 1980). The largest constituent of excreted nitrogen is ammonia, comprising over $70 \%$ of the total N-excretion (Corner and Newell, 1967; Butler et al., 1970).

In contrast, little is known of N-remineralization by microzooplankton, especially protozoans. Harrison (1978) indicates that microzooplankton of less than $183 \mu \mathrm{m}$ in diameter may be the dominant remineralization group. Johannes (1965) studied the influence of marine protozoans on P-regeneration and concluded that, although protozoans represent only a small proportion of the faunal biomass, they are the predominant source of input of animal-derived nutrients.

Our experiments were principally concerned with the excretion of ammonia by ciliates fed bacteria and algae. In this way we hoped to further the understanding of the capability of a microzooplanktonic organism for regenerating inorganic nitrogen derived from a phytoplanktonic and bacterioplanktonic biomass.

\section{MATERIALS AND METHODS}

Experiments on excretion were conducted employing the hypotrich ciliated protozoan Euplotes vannus ( 80 to $100 \times 35$ to $40 \mu \mathrm{m}$ ), originating from the North Sea and isolated by Dr. G. Uhlig. The marine bacterial strain Vibrio sp. ${ }^{1}$, and the green algae Dunaliella tertiolecta $^{2}$, served as food organisms.

Ciliates were maintained in aged, particle-free, filtered $(0.2 \mu \mathrm{m}$ Sartorius membrane filter) North Sea water diluted with distilled water to a salinity of $30 \%$ S. The starting culture of ciliates was provided with Vibriosp. on the 1 st, $3 \mathrm{rd}$ and 4 th day of cultivation and was employed for experimental purposes on the 5 th day. To remove uningested bacteria and excretory products the starting culture was repeatedly filtered. This was accomplished through careful siphoning of culture solution through a $20 \mu \mathrm{m}$ mesh until only $1 / 3$ of the initial volume remained. The original volume was restored through the addition of a particle-free, isotonic solution.

In order to enrich the bacterial culture, a seawater medium of $5 \mathrm{~g}$ yeast-extract, $1 \mathrm{~g}$ peptone, $750 \mathrm{ml}$ aged North Sea water and $250 \mathrm{ml}$ distilled water was employed (autoclaved for $20 \mathrm{~min}$ at $120^{\circ} \mathrm{C}$ ). Prior to feeding, the bacteria were washed by repeated cen-

\footnotetext{
1 Supplied by Dr. M. Rieper

${ }^{2}$ Supplied by Dr. E. Hagmeier
} 
trifuging and resuspension in particle-free, isotonic North Sea water.

The $6 \mathrm{~d}$ old starting culture of the algae Dunaliella tertiolecta was maintained in a F/10 medium (Guillard and Ryther, 1962) $30 \% \mathrm{~S}$ and placed so as to receive light from the northern sky. The ammonia content of the algal culture was negligibly small at the start of the experiment so that purifying could be waived.

To test algal metabolic influence on the $\mathrm{N}$-content of the water, a portion of the algal food suspension was irradiated with UV-light (Philips MLU $300 \mathrm{WE}$ ) for $2 \mathrm{~h}$ in a shallow dish. Inactivation of algae treated in this manner resulted in rapid reduction in primary productivity $\left({ }^{14} \mathrm{C}\right.$-method) to a level of only $2 \%$ of that of untreated algae $(=100 \%)$.

For the study of ciliate ammonia excretion, 7 parallel experiments were conducted under utmost sterile conditions in 4 l round flasks (Table 1 ).

Table 1. Experimental design

\begin{tabular}{|c|c|c|c|c|}
\hline $\begin{array}{l}\text { Experi- } \\
\text { mental } \\
\text { vessel }\end{array}$ & $\begin{array}{c}\text { Ciliates } \\
\text { Euplotes } \\
\text { vannus } \\
(50 \mathrm{ml})\end{array}$ & $\begin{array}{c}\text { Algae } \\
\text { Dunaliella } t \text {. } \\
\text { untreated } \\
(400 \mathrm{ml})\end{array}$ & $\begin{array}{c}\text { Algae } \\
\text { Dunaliellat. } \\
\text { UV- } \\
\text { irradiated } \\
(400 \mathrm{ml})\end{array}$ & $\begin{array}{l}\text { Bacteria } \\
\text { Vibriosp. } \\
(50 \mathrm{ml})\end{array}$ \\
\hline 1 Control & + & & & \\
\hline 2 & + & & & + \\
\hline 3 Control & & & & + \\
\hline 4 & + & + & & \\
\hline 5 & + & & + & \\
\hline 6 Control & & + & & \\
\hline 7 Control & & & + & \\
\hline
\end{tabular}

The flasks were filled with particle-free, aged, $30 \% \mathrm{~S}$ North Sea water to a volume of $2 \mathrm{l}$ and, thereafter, incubated in the dark at $25^{\circ} \mathrm{C}$. After shaking, flasks were sampled about every $3 \mathrm{~h}$ for the first $24 \mathrm{~h}$. A few further samples were drawn until termination of the experiment after $67 \mathrm{~h}$. Algal and bacterial numbers were assessed microscopically using acridine orange fluorescence (Zimmermann et al., 1978).

Ciliates were isolated by filtration through $0.4 \mu \mathrm{m}$ Unipore filter, stained for 10 min with $2 \%$ Erythrosine in a $5 \%$ aqueous phenol solution, then counted under the stereo-microscope. Ammonia content ( $\mu \mathrm{mol} \mathrm{N} \mathrm{l}^{-1}$ ) was determined according to Graßhoff (1968).

\section{RESULTS}

\section{Ciliate growth}

Euplotes vannus nourished on bacteria as well as on algae produced a characteristic growth curve (Fig. 1a, b).

With algal food (Dunaliella, UV-Dunaliella) an $18 \mathrm{~h}$ lag-phase was observed, with an adjustment by the ciliates (previously cultivated with bacteria) to the new food organisms. Thereafter, the ciliate population steadily increased and after $35 \mathrm{~h}$ attained 112 ciliates $\mathrm{ml}^{-1}$ with Dunaliella tertiolecta as food. With UVDunaliella, accompanied by considerable bacterial growth (see below), there were 199 ciliates $\mathrm{ml}^{-1}$ after $44 \mathrm{~h}$. Following a barely recognizable stationary phase a distinct drop in the number of ciliates occurred (death phase).

With bacterial diet (Vibrio sp.) the ciliates, already adapted to this form of nourishment, grew somewhat irregularly, but without lag period. Towards the end of this logarithmic growth the ciliates reached a maximum of 153 cells $\mathrm{ml}^{-1}$.

In control flasks with unnourished protozoans, the number of individuals did not exceed $20 \mathrm{ml}^{-1}$. When bacterial or algal foodstuff was present, generation time during logarithmic growth was 6.2 to $6.9 \mathrm{~h}$ at $25^{\circ} \mathrm{C}$.
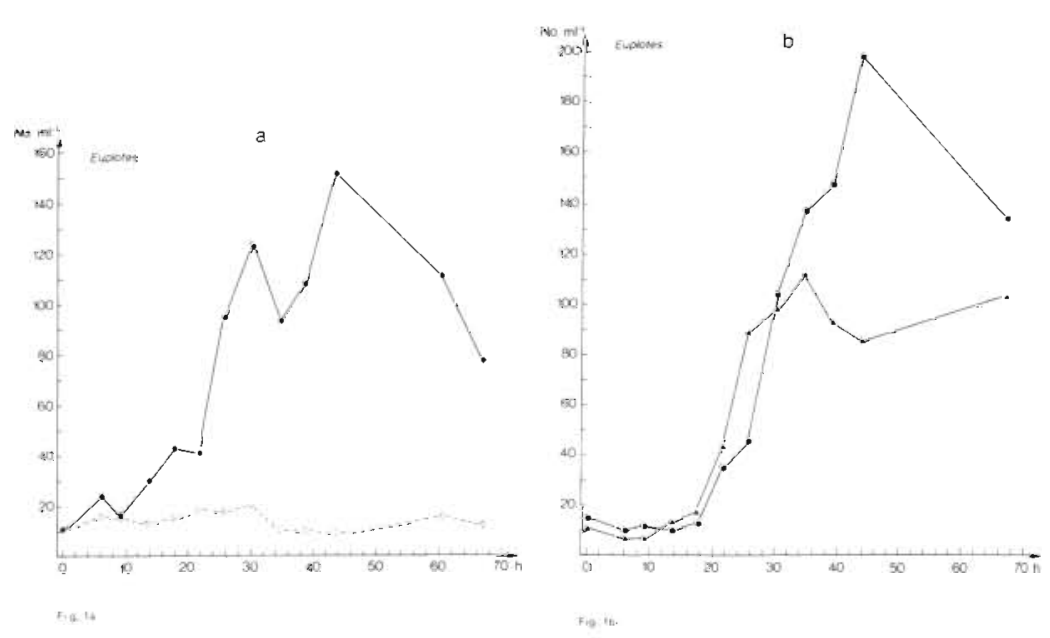

Fig. 1. Euplotes vannus. Population growth during feeding experiments (a) with bacteria Vibrio sp. (filled rhombs), without bacteria as control (open rhombs): (b) with algae Dunaliella tertiolecta (filled triangles) and UV -treated $D$. tertiolecta (filled circles) 


\section{Food consumption}

Changes in concentration of the food organisms offered (Vibrio sp., Dunaliella, UV-Dunaliella) were directly proportional to the development of ciliates (Euplotes vannus). The development of bacterial and algal numbers is presented in Fig. 2. Since the Dunaliella culture contained accompanying bacteria the latter were continually held under close surveillance, although they only represent a small contribution to the whole biomass ( $14.5 \%$ based on volume) (Fig. 2b, c)

With a purely bacterial diet (Vibriosp.) a progressive reduction in the Vibrio population was strongly correlated with an increase in ciliates. In the absence of ciliates, bacterial counts remained more or less constant during the experiment (Fig. 2a).

Although somewhat temporarily prolonged, a similar 'predator-prey' relationship is displayed by untreated chlorophyceae. Whereas Dunaliella cells were still capable of division during the first $10 \mathrm{~h}$ of the experiment, the ciliates were in a lag phase and consequently the number of algal cells initially increased slightly. When the protozoans proliferated rapidly, sharp decline in phytoplankton commenced, finally resulting in their disappearance. The number of bacteria and their total biomass accompanying the algal food organisms remain constantly low in this system and, therefore, can hardly be of significance for the nourishment of Euplotes vannus (Fig. 2b).

A different picture resulted with Euplotes vannus fed on UV-Dunaliella (Fig. 2c). Through intensive UVirradiation ca. $80 \%$ of the algal cells were lysed. The organic and inorganic compounds (see below) subsequently released were utilized by the bacteria contained within the culture leading to an enormous bacterial production $\left(33 \times 10^{6}\right.$ bacteria $\mathrm{ml}^{-1}$, after $67 \mathrm{~h}$, Fig. 2c). However, in the presence of ciliates these accompanying bacteria were steadily consumed, with the remaining UV-Dunaliella; hence the bacterial population was held at a low level $\left(4 \times 10^{6}\right.$ bacteria $\mathrm{ml}^{-1}$ ). In this case the conversion of algal biomass into ciliate biomass occurred mainly via the bacteria.

\section{$\mathrm{NH}_{4}$-excretion by ciliates}

Decomposing organic compounds (especially proteins) derived from food, the ciliates released considerable quantities of ammonia into the water (Fig. $3 a, b$ ).
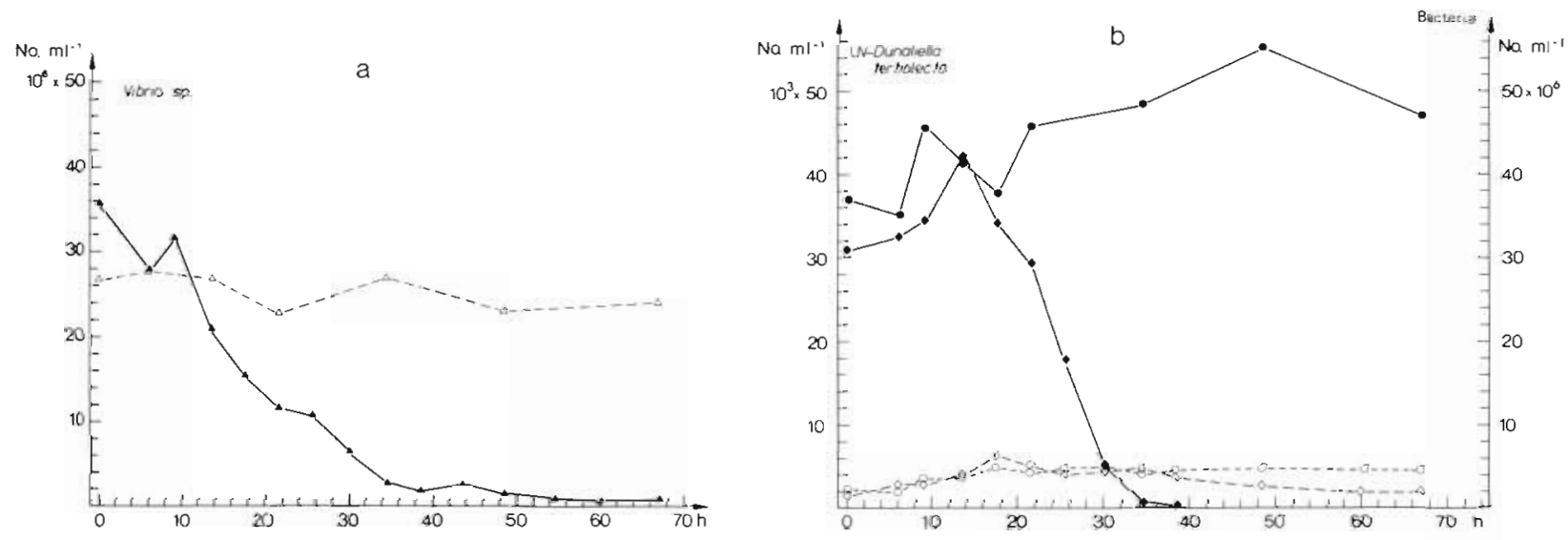

Fig. 2. Euplotes vannus. Decline of food organisms when feeding on (a) bacteria Vibrio sp. (filled triangles), bacteria control without ciliates (open triangles); (b) untreated algae Dunaliella tertiolecta (filled rhombs) and its accompanying bacteria (open rhombs), and $D$. tertiolecta without ciliates as control (filled circles), including accompanying bacteria (open circles); (c) UVtreated $D$. tertiolecta (filled triangles), and UV-D. tertiolecta without ciliates as control (filled circles), and accompanying bacteria (open circles)

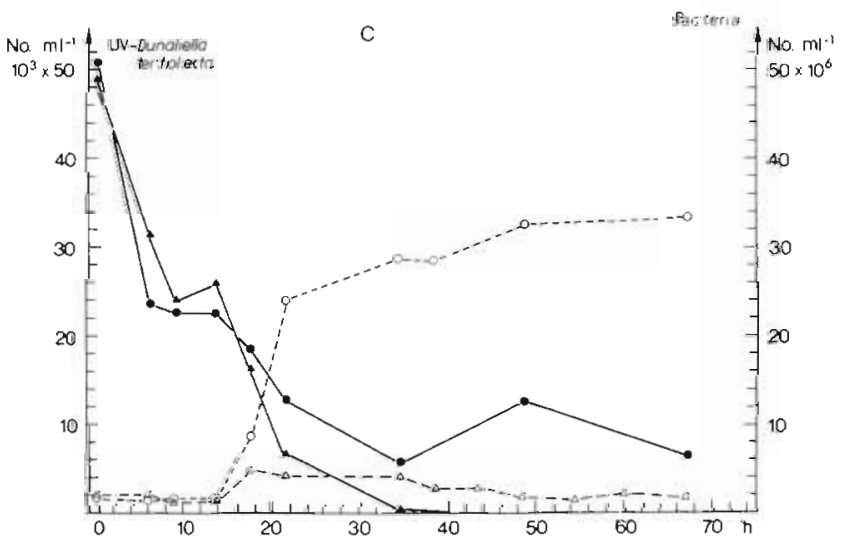



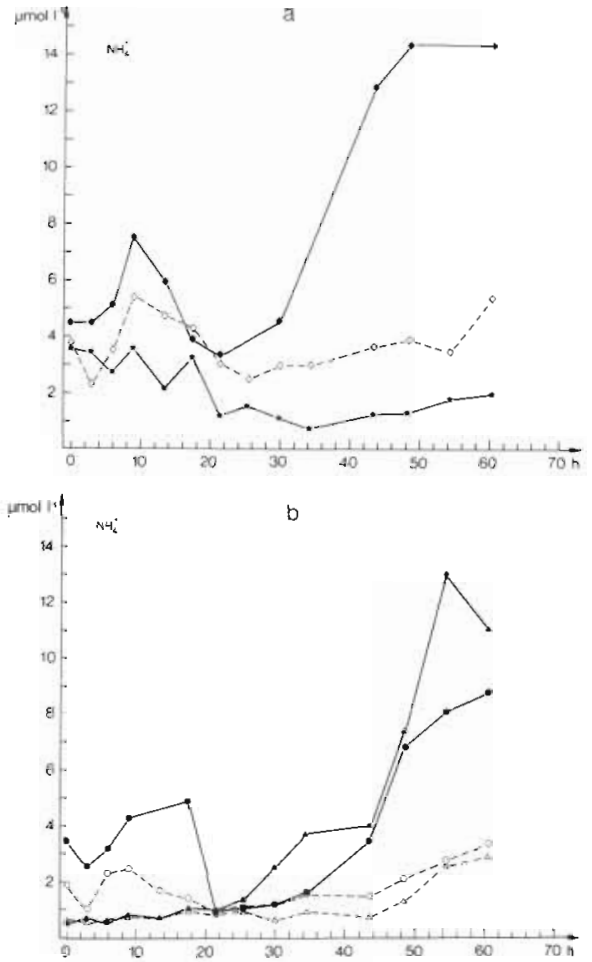

Fig. 3. Euplotes vannus. Alterations of dissolved ammonia during feeding. (a) with bacteria Vibrio sp. (filled rhombs), bacteria without ciliates (open rhombs), and unfed ciliates (asterisks) as controls; (b) with algae Dunaliella tertiolecta (filled triangles), $D$. tertiolecta without ciliates as control (open triangles), an UV-treated $D$. tertiolecta (filled circles), as well as UV-treated $D$. tertiolecta without ciliates (open circles) as control

Nevertheless, processes other than excretion by ciliates also produced recognizable alterations in the ammonia content of the culture medium.

When bacteria (Vibrio sp.) were offered as food, a small $\mathrm{NH}_{4}$-peak was observed after $9.5 \mathrm{~h}$. This peak was presumably not the result of grazing, but seems directly attributable to the food organisms themselves, as suggested by the graph obtained from the ciliatefree control (Fig, 3a).

Only through distinct proliferation of ciliates did the sudden rise in the $\mathrm{NH}_{4}$-concentration of the culture medium commence. Under these conditions a maximal excretion of $11.03 \mu \mathrm{mol} \mathrm{N}{ }^{-1}$ was attained by Euplotes vannus fed with bacteria.

With UV-irradiated algae it was noted that indeterminable quantities of inorganic and organic compounds, which influenced the ammonia content of the water as well as the development of bacteria, were released by lysis of algal cells. N-remineralization by ciliates, however, was of considerably greater consequence.

The untreated algal cells exhibit no measurable influence on $\mathrm{NH}_{4}$-concentration in the water for the first $20 \mathrm{~h}$ (Fig. 3b). Incubation in the dark apparently prevented $\mathrm{N}$-comsumption by Dunaliella tertiolecta. After ingestion of algal food by Euplotes vannus, excretion of ammonia was evident. The release of ammonia continued during the stationary phase of ciliate growth. Maximal concentration, achieved by $E$ vannus nourished on untreated $D$. tertiolecta,

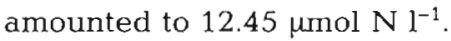

\section{DISCUSSION}

Considerable amounts of ammonia in the form of excretory products were released during utilization of algal and bacterial biomasses for ciliate growth. Excretion rate, an indication of the extent of remineralization, was expressed as $\mu$ mol nitrogen excreted by 1 ciliate ceil $\mathrm{h}^{-1}$; it was determined during logarithmic growth by using the following equation:

$$
\mathrm{e}=\frac{\mathrm{a}_{2}-\mathrm{a}_{1}}{\mathrm{x} \cdot \mathrm{t}}
$$

where $e=$ rate of excretion; $a_{2}-a_{1}=$ amount of ammonia excreted between 2 successive samplings within the log-phase; $\mathrm{t}=$ time between 2 successive samplings; $\mathrm{x}=$ number of ciliates at $\mathrm{t} / 2$. During logarithmic growth of Euplotes vannus the rate was $0.22 \times 10^{-5} \mu \mathrm{mol} \mathrm{N}$ ciliate $\mathrm{h}^{-1}$ using Dunaliella tertiolecta as nourishment, and $0.41 \times 10^{-5} \mu \mathrm{mol} \mathrm{N}$ cilitate $^{-1} \mathrm{~h}^{-1}$ with a bacterial diet. Dependence on the food organisms offered was probably due to differing availabilities of the respective food biomasses.

The small size of ciliates is closely associated with a high turnover rate and short generation time. For Euplotes vannus we determined a generation time of 6.2 to $6.9 \mathrm{~h}$ at $25^{\circ} \mathrm{C}$. For marine benthic ciliates, Fenchel (1968) calculated generation times ranging from $2.4 \mathrm{~h}$ (at $20^{\circ} \mathrm{C}$ for Uronema marinum) to $46 \mathrm{~h}$ (at $20^{\circ} \mathrm{C}$ for Condylostoma patulum). The relatively high degree of metabolic activity of ciliates, as opposed to that of marine crustaceans, permits an interesting comparison of the excretory rates of these 2 groups. Comparison with macrozooplankton, however, is complicated by the dissimilarity of experimental conditions reported in numerous publications. Nevertheless, reference to Quetin et al. (1980) may in this case be helpful. The authors investigated 19 planktonic species of crustaceans. The test animals were individually transferred into nutrient-free, filtered seawater a few hours following sorting and isolation. They were then maintained for several hours at $5.5^{\circ} \mathrm{C}$; at the beginning and end of the experiment the ammonia content in their respective containers was measured. In this manner excretory rates of between $1.4 \mu \mathrm{g}$ at $\mathrm{N} \mathrm{g}^{-1}$ wet weight $h^{-1}$ and $0.02 \mu \mathrm{g}$ at $\mathrm{N} \mathrm{g}^{-1}$ wet weight $\mathrm{h}^{-1}$ were 
obtained. An average value of $0.3 \mu \mathrm{mol} \mathrm{N} \mathrm{g}^{-1}$ wet weight $\mathrm{h}^{-1}$ for the 19 species was calculated. Since biological reactions increase in rate by a factor of 2 to 3 with a corresponding increase in temperature of $10^{\circ} \mathrm{C}$ (e.g. McLaren, 1963), the corrected rate of excretion for these crustaceans can be assumed to be about $1.9 \mu \mathrm{mol}$ $\mathrm{N} \mathrm{g}^{-1}$ wet weight $\mathrm{h}^{-1}$. If we also consider the excretory rates obtained in our study in terms of the animals' wet weight ${ }^{\circ}$, an average value of $40 \mu \mathrm{mol} \mathrm{N} \mathrm{g}^{-1}$ wet weight $\mathrm{h}^{-1}$ is observed for E. vannus at $25^{\circ} \mathrm{C}$. According to this calculation ammonia regeneration by $E$. vannus is about 20 times faster than by marine crustaceans. A greater remineralizing ability of ciliates than of marine crustaceans was similarly documented for P-generation; Johannes (1965): 'Per unit weight marine protozoa excrete dissolved phosphorus 1 to 2 orders of magnitude faster than marine macrofauna.' Barsdate et al. (1974) studied the phosphorus cycle in decomposing plant material and bacteria with and without bacterial grazers. They pointed out that phosphorus cycling is more rapid in systems with protozoans, although excretion by protozoans is minor, with the increase being mainly due to stimulating bacterial activity. On the other hand, Taylor and Lean (1981) doubt whether microzooplankton with their relatively small biomass can regenerate dissolved phosphorus much more rapidly than larger zooplanktonic crustaceans. Smetacek (1981) compared protozooplanktonic and metazooplanktonic biomasses and concluded that during periods of major development in spring and autumn protozooplankton of the Kiel Bight attain biomass values approaching those characteristic of metazooplankton in summer $\left(0.5 \mathrm{~g} \mathrm{C} \mathrm{m}^{-2}\right)$. Nevertheless, employing size fractionation, Harrison (1978) has indicated that in coastal water bodies microplankton $(<183 \mu \mathrm{m})$ may well be the primary remineralizers of nitrogen. Furthermore, as reported by Harrison (1978), Johansen (1976) has shown that specific $\mathrm{NH}_{4}$-excretory rates for tintinnids are 1 or 2 orders of magnitude higher than rates for macrozooplankton. However, assessments of preserved samples tend to underestimate protozooplankton biomass (Scharf, 1979).

Our investigations and those reported in literature indicate that, on the basis of their high metabolic activities, ciliates can contribute significantly and very quickly to the regeneration of nutrients. Of course, along with excretion a series of other processes are involved in nutrient regeneration. Decomposition of organic compounds through bacterioplankton (von Brand et al., 1937; Goltermann, 1964; and others) and autolysis of planktonic cells leads to the release of a certain amount of inorganic nutrients (Hoffmann,

- Calculated from cellular volume as determined by the light and electron microscopical examination of 200 ciliates
1956). Furthermore, nutrient release from the sediment directly influences the production of phytoplankton (von Bodungen et al., 1976).

The interaction between ciliates and bacteria appears complicated. On the one hand, bacteria serve as nourishment for the ciliates, thereby promoting ciliate production. On the other hand, development of the bacterial population is halted at a stage of 'physiological youth' due to grazing and, consequently, the attainment of a self-restricting cell-number is never realized. This phenomenon in turn promotes a bacterially effected remineralization. Further studies must be conducted in order to obtain information concerning the extent to which microzooplankton contribute to the total cycle of the regeneration of inorganic nutrients.

Acknowledgements. The authors wish to thank Mrs. D. Knoke for assistance during the experiments and Dr. E. Hartwig for verifying the ciliate species. The work was supported by the Bundesministerium for Research and Technology, BMFT Grant No. V. 9

\section{LITERATURED CITED}

Barsdate, R. J., Prentki, R. T., Fenchel, T. (1974). Phosphorus cycle of model ecosystems: significance for decomposer food chains and effect of bacterial grazers. Oikos 25: 239-251

Bodungen, B., von, Gocke, K., Smetacek, V., Zeitzschel, B (1976). The effect of sediment flushing by density displacement of interstitial water on pelagic primary production and microbial activity. Kieler Meeresforsch. (Sonderh.) 3: 87-95

Brand, T., von, Rakestraw, N. W., Renn, C. E. (1937). The experimental decomposition and regeneration of nitrogenous organic matter in the sea water. Biol. Bull. mar. biol. Lab., Woods Hole 72: 165-175

Butler, E. J., Corner, E. D. S., Marshall, S. M. (1969). On the nutrition and metabolism of zooplankton: VI Feeding efficiency of Calanus in terms of nitrogen and phosphorus. J. mar. biol. Ass. U. K. 49: 977-1001

Butler, E. J., Corner, E. D. S., Marshall, S. M. (1970). On the nutrition and metabolism of zooplankton: VII Seasonal survey of nitrogen and phosphorus excretion by Calanus in the Clyde Sea area. J. mar. biol. Ass. U. K. 50: 525-560

Conover, R. J., Corner, E. D. S. (1968). Respiration and nitrogen excretion by some marine zooplankton in relation to their life cycle. J. mar. biol. Ass. U. K. 48: 49-75

Conover, R. J., Mayzaud, P. (1976). Respiration and nitrogen excretion of neritic zooplankton in relation to potential food supply. In: Persoone, G., Jaspers, E. (ed.) Proceedings of the 10th European Marine Biology Symposium, Vol. 2. Universa Press, Ostend, p. 151-163

Corner, E. D. S., Newell, B. S. (1967). On the nutrition and metabolism of zooplankton: IV The forms of nitrogen excreted by Calanus. J. mar. biol. A.ss. U. K. 47: 113-121

Fenchel, T. (1968). The ecology of marine microbenthos. III. The reproductive potential of ciliates. Ophelia 5: 123-136

Goltermann, H. L. (1964). Mineralization of algae under sterile conditions or by bacterial breakdown. Verh. int. Verein. theor. angew. Limnol. 15: 544-548

Graßhoff, K. (1968). Über eine empfindliche und direkte Methode zur automatischen und manuellen Bestimmung 
von Ammoniak im Meerwasser. Z. analyt. Chem. 234; $13-22$

Guillard, R. R. L., Ryther, J. H. (1962). Studies of planktonic diatoms. I Cyclotella nana Hustedt and Detonula confervacea (Cleve) Gran. Can. J. Microbiol. 8: 229-239

Harris, E. (1959). The nitrogen cycle in Long Island Sound. Bull. Bingham Oceanogr. Coll. 17: 31-65

Harrison, W. G. (1978). Experimental measurements of nitrogen remineralization in coastal waters. Limnol. Oceanogr. 23 (4): 684-694

Hoffmann, C. (1956), Untersuchungen über die Remineralisierung des Phosphors im Plankton. Kieler Meeresforsch. (Sonderh.) 12: 25-36

Johanes, R. E. (1965). Influence of marine protozoa on nutrient regeneration. Limnol. Oceanogr. 10: 434-442

Johannsen, P. L. (1976). A study of tintinnids and other protozoa in eastern Canadian waters with special reference to tintinnid feeding, nitrogen excretion and reproduction rates. Ph. D. thesis, University of Dalhousie
McLaren, J. A. (1963). Effects of temperature on growth of zooplankton and the adaptive value of vertical migration. J. Fish. Res. Bd Can. 20: 685-727

Quetin, L. B., Ross, R. M. Uchio, K. (1980). Metabolic characteristic of midwater zooplankton: ammonia excretion, $\mathrm{O}: \mathrm{N}$ ratios, and the effect of starvation. Mar. Biol. 59: 201-209

Scharf, E.-M. (1979). Die Bedeutung benthischer heterotropher Protozoen (Ciliaten) im Stoffkreislauf und Energiefluß eines mesohalinen Brackgewässers (Barther Bodden). Ph. D. thesis, Rostock University

Smetacek, V. (1981). The annual cycle of protozooplankton in Kiel Bight. Mar. Biol. 63: 1-11

Taylor, W. D., Lean, D. R. S. (1981). Radiotracer experiments on phosphorus uptake and release by limnetic microzooplankton. Can. J. Fish. aquat. Sci. 38: 1316-1321

Zimmermann, R., Iturriaga, R, Becker-Birck, J. (1978). Simultaneous determination of the total number of aquatic bacteria and the number thereof involved in respiration. Appl. environ. Microbiol. 36 (6): 926-935 